\title{
Modulation of Abamectin and Indoxacarb -Induced Toxicity on Male Albino Rats by Moringa oleifera
}

\author{
Mona A. Abdelrasoul ${ }^{1}$
}

\begin{abstract}
Pesticide formulations are characterized by its complex mixtures.The available toxicity information on the active ingredients alone is not quit enough to evaluate the risk of undesirable health effects of commercial pesticides. Therefore, the present study was proposed to clarify the adverse effects of exposure to formulated abamectin (ABA) $\left(0.5 \mathrm{mg} / \mathrm{kg} \mathrm{bw}, 1 / 20 \mathrm{LD}_{50}\right)$, indoxacarb (IND) $\left(86.6 \mathrm{mg} / \mathrm{kg} \mathrm{bw}, 1 / 20 \mathrm{LD}_{50}\right)$ and their combinations on some haematological and biochemical parameters and histopathological changes of male rats given repetitive oral doses for 30 consecutive days. The protective effect of aqueous extract of Moringa oleifera leaves (MO) against toxicity induced by tested insecticide was, also, considered. Results indicated that ABA, IND, and their combination treatments, significantly, caused gradual decreasing in body weight, erythrocyte counts (RBCs), haemoglobin concentration (g/dL), haematocrit (\%) and platelets (PLT). However, significant elevation in the relative liver, kidney and brain weights were associated with these treatments. Marked and significant increments in the levels of serum alkaline phosphatase (ALP), alanine aminotransferase (ALT), aspartate aminotransferase (AST), gammaglutamyltransferase $(\gamma$-GT), glucose concentration and creatinine (Cre), while decrease in serum acetylcholinesterase (AChE) activity was observed due to tested insecticide treatments. Exposure to ABA and IND, significantly decrease the total protein and total antioxidant scavenging activity. Histological studies confirmed the biochemical parameters. M. oleifera leavestreated rats with ABA, IND or their combinations showed marked improvements of hematological, biochemical parameters and histopathological changes, indicating that MO extract bear a potent antioxidant activity. Therefore, the successive aqueous extract of MO as an herbal tea may be beneficial for patients who suffer from liver, kidney and brain diseases and restoring the damage sustained by insecticide exposure.
\end{abstract}

Keywords:Rats, Abamectin, Indoxacarb; biomarkers, Histopathology, Moringa, modulation

\section{INTRODUCTION}

Pesticide development and synthesis is an ongoing process to overcome the increasingly destructive effects of various plant and animal pathogens. Abamectin (ABA)and indoxacarb (IND) are examples of these newly developed and widely used pesticides with high toxicity against plant pathogens (Zanoli et al., 2012).
$\mathrm{ABA}$ is a versatile pesticide that is used worldwide as an insecticide, nematicide, acaricide and/or antiparasitic agent for livestock (Tomlin 2004; Kolar et al., 2008) and might induce mammalian toxicity (AbdElhady and Abou-Elghar, 2013). Liver and fat tissues of rats exhibited high levels of $\mathrm{ABA}$ as reported by Gonzalez et al., (2009).

IND is characterized by its high toxicity against several agricultural pests (Wing et al., 1998; Park et al., 2011). It is a pro-insecticide, so that it must be biologically-activated to the more effecttive metabolite,N-decarbomethoxyllated, in insects (Von Stein et al., 2013). The same bioactivation process occurs in mammals, but at a slower conversion rate that favors the insecticide selective toxicity. Human toxicity was characteri-zed by alteration in blood cell count (RBCs) due to indoxacarb treatment (Sandeep et al. 2016), while, delayed toxicity in mice and rats was observed (Shit et al. 2008). Deleterious effects on lipid and protein contents, superoxide dismutase, and catalase enzyme activities of mice dosed with $6,8,12$ and 24 $\mathrm{mg} / \mathrm{kg} / \mathrm{day}$ for 30 days were detected (Mudaraddi et al., 2012).

Herbal plants are phytomedicinal agents and proven to have hepatoprotective (Huang et al.,2012; Abdel Rasoul and Marei, 2016), anti-diabetic, anti-pyretic, diuretic effects (Sharma et al., 2012). The moringa (Moringa oleifera, MO) has vast therapeutic properties due to the presence of essential amino acids (methionine, tryptophan, cysteine, and lysine), $\beta$ carotene, protein, vitamins, minerals $(\mathrm{Ca}$ and $\mathrm{K})$, and several phenolic compounds (Ndong et al. 2007; Verma et al., 2009; Khalafalla et al., 2010; Vongsak et al., 2012). Moreover, the aqueous extract of MO enhanced the hepatic glutathione restoration (Fakurazi et al., 2008). Hence, the present study was undertaken to evaluate the ameliorative effects of leaf aqueous extract of $\mathrm{MO}$ onabamectin and indoxacarb induced toxicity to male albino rats.

\section{MATERIALS AND METHODS}

\section{Chemicals}

The commercial formulations of ABA (Vertemic ${ }^{\circledR}$, $1.8 \%$ EC) and IND (Avaunt ${ }^{\circledR}, 15 \%$ SC) were supplied by Syngenta Agro Services AG, Egypt. The 2,2'-Azino-

${ }^{1}$ Plant Protection Department, Faculty of Agriculture,

Damanhour University, Damanhour, Albeheira, 22516

E-mail: mona.abdelnaby@agr.dmu.edu.eg

Received April 13, 2018, Accepted May 10, 2018 
bis(3-ethyl-benzo-thiazoline-6-sulphonic acid) (ABTS), potassium persulfate $\left(\mathrm{K}_{2} \mathrm{~S}_{2} \mathrm{O}_{8}\right)$ and trolox were purchased from Sigma-Aldrich, Germany. The enzymatic assay kits were purchased from BioDiagnostics Co., Dokki, Giza, Egypt. All other chemicals and solvents were of analytical grade.

\section{Preparation of the aqueous extract of M.oleifera and GC-MS analysis}

Fresh mature leaves of MO were collected from Faculty of Agriculture farm, Damanhour University, AlBostan region, El-Beheira Governorate. The leaves were dried at $65^{\circ} \mathrm{C}$ in oven (Puriven, Korea) and ground into fine powder. Approximately $2 \mathrm{~g}$ of the powder was boiled in $1 \mathrm{~L}$ of de-ionized water for $10 \mathrm{~min}$ and then stored at $4^{\circ} \mathrm{C}$. The acute oral toxicity study of M. oleifera $\left(\mathrm{LD}_{50}\right)$ was found to be greater than 5000 $\mathrm{mg} / \mathrm{kg}$ (Asiedu-Gyekye et al., 2014).

Approximately, $2 \mathrm{ml}$ of the extract were filtered into a 2-ml dark glass vial using a $1 \mathrm{ml}$ syringe and a $0.2 \mu \mathrm{m}$ nylon filter (Fisher Scientific, Ottawa, Canada). Then one $\mu l$ of the sample was injected into an Agilent 6890 Gas Chromatography-Mass Spectrometry (GC-MS) system. The GC-MS was equipped with an Agilent mass spectrometric detector, with a direct capillary interface and fused silica capillary column PAS-5 MS (30 $\mathrm{mm} \times 0.25 \mu \mathrm{m}$ film thickness). Helium was the carrier gas $(36 \mathrm{~cm} / \mathrm{sec})$ at flow rate of $1 \mathrm{ml} / \mathrm{min}$ and the solvent delay time was $3 \mathrm{~min}$ was set. The mass spectrophoto-metric detector was operated in an electron impact ionization mode with the energy of $70 \mathrm{eV}$ and the scanning mode from 50 to 500 mass/charge $(\mathrm{m} / \mathrm{z})$. The ion source temperature was $230{ }^{\circ} \mathrm{C}$ and the quadrupole temperature was $150{ }^{\circ} \mathrm{C}$. The electron multiplier voltage (EM voltage) was maintained $1250 \mathrm{v}$ above the auto-tune. The instrument was manually tuned using perfluorotributyl-amine (PFTBA). The GC temperature program was started at $60{ }^{\circ} \mathrm{C}$ for $3 \mathrm{~min}$ then elevated to $280{ }^{\circ} \mathrm{C}$ at a rate of $8{ }^{\circ} \mathrm{C} / \mathrm{min}$ and $10 \mathrm{~min}$ hold at $280^{\circ} \mathrm{C}$. The $\mathrm{m} / \mathrm{z}$ ratio obtained was calibrated from the mass spectrum graph, which is the fingerprint of each molecule. Moreover, identification of the separated peaks was done using the Wiley9 and NIST5 mass spectral data-base.

\section{Experimental procedure}

Adult male albino rats (Rattus norvegicus; $120 \pm 5 \mathrm{~g}$ ) were obtained from the animal house, Faculty of Medicine, Alexandria University, Egypt. Animals were housed in clean transparent plastic cages $(28$ X 45 X 25 $\mathrm{cm})$ at $25 \pm 2 \mathrm{C}^{\circ}$ with $12 \mathrm{~h}$ dark/light photoperiod and $70 \pm 10 \%$ humidity. The animals were acclimatized to the laboratory conditions for 2 weeks before executing the experiments. Animals were fed on balanced commercial diet and water ad libitum. Handling of the experimental animals was consistent with the international ethics of the care and use of experimental animals (National Research Council, 2011).

Rats were divided into 8 groups of 6 adult males each. Group 1 (control) and group 2 was given the aqueous $\mathrm{MO}$ as the sole drinking fluid at a dose of 200 $\mathrm{mg} / \mathrm{kg} \mathrm{bw}$ ). In group $3 \mathrm{ABA}$, rats were administered $1 / 20 \mathrm{LD}_{50}(0.5 \mathrm{mg} / \mathrm{kg} \mathrm{bw})$ of ABA $\left(\mathrm{LD}_{50}=10 \mathrm{mg} / \mathrm{kg}\right.$ bw, Tomlin, 2005). Group 4 IND of rats were intoxicated with $1 / 20 \mathrm{LD}_{50}(86.6 \mathrm{mg} / \mathrm{kg} \mathrm{bw})$ of IND $\left(\mathrm{LD}_{50}=1730 \mathrm{mg} / \mathrm{kg}\right.$ bw, Tomlin, 2005). Group 5 (ABA and IND) of rats were given $1 / 20 \mathrm{LD}_{50}$ of $\mathrm{ABA}$ and $1 / 20 \mathrm{LD}_{50}$ of IND. Rats in groups 6, 7, and 8 were given the same doses of insecticides in groups 3, 4 and 5, respectively and allowed to drink the aqueous MO extract as the sole source of drinking fluid. Rats were orally administered the doses for 30 consecutive days. Initial and final body weights of male rats were recorded to calculate relative weight changes according to Chapman et al.,(1959).

\section{Blood sampling and tissue organs}

After $12 \mathrm{~h}$ of the administration of the last dose, rats were sacrificed under ether anesthesia and then blood samples were collected from aortic artery into EDTA$\mathrm{K}_{3}$ tubes for blood picture assays and non-heparinized tubes for serum separation. Blood samples were allowed to clot at room temperature for $15 \mathrm{~min}$, and then centrifuged at $3000 \mathrm{rpm}$ (Universal 32R, Hettich Zentrifugen model D-78532, Germany) for $10 \mathrm{~min}$. Serum samples were kept frozen at $-20 \mathrm{C}^{\circ}$ until assayed. Liver, kidney, and brain were dissected and then kept in $10 \%$ formalin solution in a screw-cap $50 \mathrm{ml}$ tubes for histological studies.

\section{Hematological measurements}

The EDTA-K $\mathrm{K}_{3}$ blood samples analyzed for the blood picture using the automated Sysmex apparatus (Sysmex KX21, Japan) in a certified clinical laboratory. The parameters included white blood cells count (WBCs, $\times$ $10^{3} / \mathrm{mm}^{3}$ ), red blood cells count (RBCs, $\times 10^{3} / \mathrm{mm}^{3}$ ), hemoglobin concentration $(\mathrm{Hb}, \mathrm{g} / \mathrm{dl})$, haematocrit value (PCV \%) andplatelets (PLT, $\times 10 / \mathrm{mm}^{3}$ ).

\section{Biochemical analysis}

The biochemical assays of enzymes of the serum samples were done colorimetry using available commercial diagnostic kits. AST and ALT activities were detemined according to Reitman and Frankel (1957), while ALP, $\gamma$-GTand AChE were determined according to Young et al. (1975), Whitfield et al. (1973) and Ellman et al. (1961), respectively. Concentrations of glucose, total protein and creatinine were measured according to the methods of Tietz (1995), Gornal et al., (1949) and Barham and Trinder (1972), respectively. 


\section{ABTS radical-scavenging capacity assay}

A solution of ABTS was prepared by the reaction of ABTS $(7 \mathrm{mM} / \mathrm{L})$ and potassium persulfate $(2.45 \mathrm{mM} / \mathrm{L})$ after incubation at $23 \mathrm{C}^{\circ}$ in the dark for $12 \mathrm{~h}$ (Re et al., 1999). The ABTS solution was then diluted with $80 \%$ $(\mathrm{v} / \mathrm{v})$ aqueous ethanol to obtain an absorbance of $0.70 \pm$ 0.02 at $731 \mathrm{~nm}$. About $300 \mu \mathrm{l}$ of the serum samples were mixed with $1.2 \mathrm{ml}$ of the diluted ABTS solution. The reaction mixture was incubated at $23 \mathrm{C}^{\circ}$ for $8 \mathrm{~h}$ in dark and the absorbance was measured at $731 \mathrm{~nm}$ using a UV-Vis spectrophotometer (pg Instruments T20, England). The ABTS scavenging activity was calculated as $\mu \mathrm{M}$ trolox equivalent $/ \mathrm{ml}$ serum based on a standard curve of trolox $(0-15 \mu \mathrm{M})$.

\section{Histological studies}

Liver, kidney and brain organs were excised and fixed in $10 \%$ neutral formalin buffer for histological examination. The samples were processed using graded ethanol series and embedded in paraffin. Tissue sections (5- $\mu \mathrm{m}$ thick) were cut and stained with hematoxylin and eosin (H\&E). The specimens were examined under a light microscope and photographs were taken with an automatic photomicrographic system.

\section{Statistical Analysis}

All the data are presented as mean \pm SE. Statistical analysis was performed using Statistical Package for the Social Sciences (SPSS) version 20. Statistical significance of the differences between the treatments groups were analyzed by post-test Turkey's multiple comparison tests. $p<0.05$.

\section{RERSULTS}

\section{GC-MS analysis of aqueous extract of $M$. oleifera leaves}

The chemical compounds from the GC-MS analysis were identified with NIST and Willey database libraries
(Table 1). The GC-MS analysis of aqueous extracts of MO leaves revealed the presence of 9,12Octadecadienoic acid, methyl ester $(6.18 \%)$, Deuterated etioporphyrine (5.95\%), Naphtho-1,3- dioxole -6,7dicarboxylic acid, 5,6,7,8- tetrahydro-5- hydroxy-8(3,4,5-trimethoxyphenyl (5.94\%), Quinoline, 2-[(2benzodioxol-5-yl)-5-ethenyl]-4-methoxy (5.85\%), Hexabutyl-distannousoxane (5.75\%), 1-Choloro-6hydroxy-4-methyl-11-nitronaphtho-isoquinoline-5,12quinone $(5.67 \%)$, Bromoacetic acid, 2-bromo-4fluorophenyl ester (4.75\%), 3,3,4,4`-Tetrabromo-2,2` bithiophene-5,5 -dicarbaldehyde (4.23\%).

\section{Body and relative organs weight of male albino rats}

During the study period, there were no clinical signs of toxicity in treatedrats. Body and relative brain, kidney and liver weights of rats treated treated with aqueous MO did not differ significantly control valus (Table 2). However, when rats treated with ABA, IND and their combinations, significant differences $(p<$ 0.05 ) and gradual decreasing in body weight were observed, while significant elevations in the relative liver, kidney and brain weights were detected. Unfortunately, this effect was attenuated by the treatment with MO extract to tested insecticide.

\section{Hematological effects}

Data presented in Table (3) did not reflect any significant difference in hematological parameters between $\mathrm{MO}$ extract and untreated rats. However, ABA, IND and $A B A+I N D$ caused significant decreases in RBCs, Hg (g/dL), Pcv (\%) and PLT. On the other hand, WBCs in blood samples of rats showed significant increase as compared to the control. Marked improvements in hematological parameters were observed due to administration of $\mathrm{MO}$ extract in rats treated with $\mathrm{ABA}$, IND or ABA+IND.

Table 1. Chemical composition of the aqueous extract of $M$. oleifera leaves analyzed by GC-MS

\begin{tabular}{clc}
\hline RT (min) & \multicolumn{1}{c}{ Component name } & \multicolumn{1}{c}{ Peak area (\%) } \\
\hline 4.34 & Naphtho-1,3-dioxole-6,7-dicarboxylic acid, 5,6,7,8-tetrahydro-5-hydroxy- & 5.94 \\
4.55 & 8-(3,4,5-trimethoxyphenyl) & 4.23 \\
4.72 & 3,3`,4,4-Tetrabromo-2,2-bithiophene-5,5'-dicarbaldehyde & 5.95 \\
4.87 & Deuterated etioporphyrine & 4.75 \\
7.85 & Bromoacetic acid, 2-bromo-4-fluorophenyl ester & 5.67 \\
11.34 & 1-Choloro-6-hydroxy-4-methyl-11-nitronaphtho-isoquinoline-5,12- & 5.75 \\
11.94 & quinone & 5.85 \\
23.79 & Quinoline, 2-[(2-benzodioxol-5-yl)-5-ethenyl]-4-methoxy & 6.18 \\
\hline
\end{tabular}


Table 2. Effect of abamectin, indoxacarb and their combinations on body and relative liver, kidney and brain weights of rats and the moudualtion by $M$. oleifera

\begin{tabular}{|c|c|c|c|c|c|c|}
\hline \multirow[t]{2}{*}{ Treatment } & \multicolumn{3}{|c|}{ Body weight } & \multirow{2}{*}{$\begin{array}{l}\text { Relative } \\
\text { liver }\end{array}$} & \multirow{2}{*}{$\begin{array}{l}\text { Relative } \\
\text { kidney }\end{array}$} & \multirow{2}{*}{$\begin{array}{c}\text { Relative } \\
\text { Brain }\end{array}$} \\
\hline & Initial (g) & Final (g) & \% Change/week & & & \\
\hline Control & $140.6 \pm 0.9^{\mathrm{cd}}$ & $223.1 \pm 2.2^{\mathrm{a}}$ & $14.65 \pm 0.13^{\mathrm{a}}$ & $3.55 \pm 0.0^{\mathrm{g}}$ & $0.89 \pm 0.01^{\mathrm{a}}$ & $0.56 \pm 0.0^{\mathrm{ef}}$ \\
\hline MO & $139.1 \pm 0.6^{\mathrm{d}}$ & $218.6 \pm 2.1^{\mathrm{ab}}$ & $14.29 \pm 0.22^{\mathrm{a}}$ & $3.68 \pm 0.0^{\mathrm{g}}$ & $0.90 \pm 0.02^{\mathrm{a}}$ & $0.55 \pm 0.0^{\mathrm{f}}$ \\
\hline $\mathrm{ABA}$ & $141.8 \pm 0.8^{\mathrm{bc}}$ & $195.8 \pm 1.2^{\mathrm{d}}$ & $9.53 \pm 0.20^{\mathrm{d}}$ & $4.92 \pm 0.0^{c}$ & $0.79 \pm 0.02^{\mathrm{c}}$ & $0.65 \pm 0.0^{c}$ \\
\hline IND & $141.6 \pm 1.0^{\mathrm{bc}}$ & $190.4 \pm 0.6^{\mathrm{e}}$ & $8.62 \pm 0.16^{\mathrm{e}}$ & $5.26 \pm 0.0^{\mathrm{b}}$ & $0.80 \pm 0.01^{\mathrm{c}}$ & $0.69 \pm 0.0^{\mathrm{b}}$ \\
\hline $\mathrm{ABA}+\mathrm{IND}$ & $145.9 \pm 0.6^{\mathrm{a}}$ & $190.4 \pm 0.7^{\mathrm{e}}$ & $7.62 \pm 0.15^{f}$ & $5.88 \pm 0.06^{\mathrm{a}}$ & $0.77 \pm 0.01^{\mathrm{c}}$ & $0.75 \pm 0.0^{\mathrm{a}}$ \\
\hline $\mathrm{ABA}+\mathrm{MO}$ & $143.9 \pm 0.9^{\mathrm{ab}}$ & $217.7 \pm 2.1^{\mathrm{b}}$ & $12.79 \pm 0.15^{\mathrm{b}}$ & $4.06 \pm 0.02^{\mathrm{f}}$ & $0.86 \pm 0.01^{\mathrm{b}}$ & $0.55 \pm 0.0^{\mathrm{f}}$ \\
\hline IND + MO & $141.8 \pm 0.6^{\mathrm{bc}}$ & $212.3 \pm 1.6^{\mathrm{c}}$ & $12.42 \pm 0.11^{\mathrm{b}}$ & $4.24 \pm 0.04^{\mathrm{e}}$ & $0.85 \pm 0.01^{\mathrm{b}}$ & $0.58 \pm 0.0^{\mathrm{de}}$ \\
\hline $\mathrm{ABA}+\mathrm{IND}+\mathrm{MO}$ & $141.9 \pm 0.7^{\mathrm{bc}}$ & $209.2 \pm 1.9^{\mathrm{c}}$ & $11.85 \pm 0.24^{\mathrm{c}}$ & $4.41 \pm 0.04^{\mathrm{d}}$ & $0.87 \pm 0.01^{\mathrm{ab}}$ & $0.58 \pm 0.0^{\mathrm{d}}$ \\
\hline
\end{tabular}

Each value is a mean of 6 rats \pm S.E.; Means having the same letters are not singificanly differ from each other, $p<0.05$; Relative organ weight $=($ organ weight/final body weight $) \times 100$;

$\%$ of body weight change/week $=$ [(final b .w t. - initial b .wt. $) /$ initial b .wt. $] /$ no of weeks X 100 .

\section{Biomarkers of liver and kidney dysfunctions}

The administration of MO extract did not cause any changes in all the determined biochemical parameters compared to untreated rats (Table 4). Concerning the determination of damage induced by ABA and IND and the protective effect of MO, the activities of some enzymes (ALT, AST, ALP and $\gamma$-GT) were used as hepatotoxic biomarkers. Following 30 days of tested insecticides administration, marked significant increases in liver enzyme activities were observed, indicating the occurrence of hepatic injuries. Total protein was significantly decreased $(\mathrm{P}<0.05)$ compared with control group. However, administration of $\mathrm{MO}$ extract combined with ABA, IND or ABA+IND improved most of the tested biochemical parameters.

Changes in serum on total antioxidant scavenging activity ( $\mu \mathrm{M}$ Trolox equivalent/ $\mathrm{ml}$ serum), creatinine level, total protein and glucose in various experimental groups are represented in Figure 1. It was found that MO extract increased the antioxidant activity compared to the control. Furthermore, administering $\mathrm{MO}$ with ABA, IND and their combinations increased the antioxidant capacity (Fig 1A). It was, also, noticed that

Table 3. Effect of abamectin, indoxacarb and their combinations on red blood cells (RBCs), white blood cells (WBCs), haemoglobin concentration (Hg), haematocrit (PCV) and platelets (PLT) in male albino rats and the moudualtion by $M$. oleifera

\begin{tabular}{lccccc}
\hline Treatment & $\begin{array}{c}\mathbf{W B C} \\
\left(\times \mathbf{1 0}^{\mathbf{3}} / \mathbf{m m}^{\mathbf{3}}\right)\end{array}$ & $\begin{array}{c}\mathbf{R B C} \\
\left(\times \mathbf{1 0}^{\mathbf{3}} / \mathbf{m m}^{\mathbf{3}}\right)\end{array}$ & $\begin{array}{c}\mathbf{H g} \\
(\mathbf{g} / \mathbf{d L})\end{array}$ & $\begin{array}{c}\text { PCV } \\
(\mathbf{\%})\end{array}$ & $\begin{array}{c}\text { PLT } \\
\left(\times \mathbf{1 0}_{\mathbf{m}} \mathbf{m} \mathbf{m m}^{\mathbf{3}}\right)\end{array}$ \\
\hline Control & $9.78 \pm 0.17^{\mathrm{e}}$ & $7.48 \pm 0.09^{\mathrm{a}}$ & $13.65 \pm 0.06^{\mathrm{a}}$ & $45.36 \pm 0.44^{\mathrm{a}}$ & $552.50 \pm 6.13^{\mathrm{a}}$ \\
MO & $9.80 \pm 0.11^{\mathrm{e}}$ & $7.51 \pm 0.11^{\mathrm{a}}$ & $13.66 \pm 0.08^{\mathrm{a}}$ & $44.78 \pm 0.51^{\mathrm{a}}$ & $558.66 \pm 6.32^{\mathrm{a}}$ \\
ABA & $15.76 \pm 0.14^{\mathrm{c}}$ & $4.77 \pm 0.03^{\mathrm{d}}$ & $10.25 \pm 0.21^{\mathrm{d}}$ & $38.11 \pm 0.36^{\mathrm{d}}$ & $339.33 \pm 8.26^{\mathrm{e}}$ \\
IND & $15.70 \pm 0.14^{\mathrm{c}}$ & $4.34 \pm 0.13^{\mathrm{e}}$ & $9.56 \pm 0.15^{\mathrm{e}}$ & $35.05 \pm 0.33^{\mathrm{e}}$ & $449.66 \pm 4.86^{\mathrm{d}}$ \\
ABA+IND & $21.23 \pm 0.54^{\mathrm{a}}$ & $4.24 \pm 0.08^{\mathrm{e}}$ & $8.60 \pm 0.12^{\mathrm{f}}$ & $30.68 \pm 0.19^{\mathrm{f}}$ & $314.66 \pm 12.03^{\mathrm{e}}$ \\
ABA MO & $13.04 \pm 0.14^{\mathrm{d}}$ & $6.75 \pm 0.15^{\mathrm{b}}$ & $12.76 \pm 0.13^{\mathrm{b}}$ & $41.68 \pm 0.35^{\mathrm{b}}$ & $511.50 \pm 12.81^{\mathrm{b}}$ \\
IND+MO & $13.61 \pm 0.17^{\mathrm{d}}$ & $6.53 \pm 0.11^{\mathrm{b}}$ & $12.69 \pm 0.16^{\mathrm{b}}$ & $39.05 \pm 0.45^{\mathrm{cd}}$ & $519.83 \pm 10.53^{\mathrm{b}}$ \\
ABA+IND+MO & $17.26 \pm 0.12^{\mathrm{b}}$ & $5.87 \pm 0.11^{\mathrm{c}}$ & $12.23 \pm 0.12^{\mathrm{c}}$ & $39.43 \pm 0.45^{\mathrm{c}}$ & $457.16 \pm 12.52^{\mathrm{d}}$ \\
\hline
\end{tabular}

the total creatinine content was increased as a result of administration of ABA, IND and their combinations (Fig. 1B). On the other side, AChE activity was significantly lowered $(\mathrm{P}<0.05)$ (Fig. 1C), whereas; serum glucose level was significantly elevated in treated rat as compared with control group (Fig. 1D). When MO extract was administrated to the treated rats, a marked improvement in antioxidant capacity, total creatinine content, and $\mathrm{AChE}$ and glucose level was detected.

\section{Histopathological investigations}

The histopathological alterations of liver, kidney, and brain tissues were shown in Figures (2-4). Liver sections from the control (G1) and MO (G2) rats showed normal hepatic cytoarchitecture (Figures 2 A and B). Liver lobules were significantly affected by the tested insecticides (ABA, IND and their combinations). Severe cytoplasmic vacuolation of hepatocytes was observed due to the IND (G4) toxicity, whereas; it was moderately changed after the treatment with ABA (G3), the mixture of ABA and IND (G5), and ABA mixed with MO (G6).

Each value is a mean of 6 rats \pm S.E.; Means having the same letters are not singificanly differ from each other, $p<0.05$. 
Table 4.Effect of abamectin, in doxacarb and their combinati on serum biochemical parameters and the moudualtion by $M$. oleifera

\begin{tabular}{lccccc}
\hline \multirow{2}{*}{ Treatment } & Total protein & ALP & AST & ALT & \multicolumn{1}{c}{$\gamma$-GT } \\
& g/dl & U/L & U/L & U/L & U/L \\
\hline Control & $9.82 \pm 0.19^{\mathrm{a}}$ & $115.60 \pm 0.61^{\mathrm{f}}$ & $253.46 \pm 1.19^{\mathrm{d}}$ & $136.51 \pm 0.76^{\mathrm{f}}$ & $21.46 \pm 0.47^{\mathrm{a}}$ \\
MO & $9.59 \pm 0.12^{\mathrm{a}}$ & $114.98 \pm 1.51^{\mathrm{f}}$ & $254.26 \pm 1.33^{\mathrm{cd}}$ & $137.70 \pm 0.99^{\mathrm{f}}$ & $21.73 \pm 0.49^{\mathrm{a}}$ \\
ABA & $7.43 \pm 0.08^{\mathrm{d}}$ & $148.86 \pm 0.96^{\mathrm{c}}$ & $278.33 \pm 2.58^{\mathrm{b}}$ & $158.65 \pm 1.67^{\mathrm{d}}$ & $11.69 \pm 0.55^{\mathrm{d}}$ \\
IND & $8.09 \pm 0.13^{\mathrm{c}}$ & $158.34 \pm 1.31^{\mathrm{b}}$ & $279.57 \pm 1.77^{\mathrm{b}}$ & $166.56 \pm 1.87^{\mathrm{c}}$ & $10.54 \pm 0.27^{\mathrm{e}}$ \\
ABA+IND & $5.90 \pm 0.18^{\mathrm{e}}$ & $187.78 \pm 1.21^{\mathrm{a}}$ & $291.19 \pm 2.24^{\mathrm{a}}$ & $198.49 \pm 1.69^{\mathrm{a}}$ & $7.42 \pm 0.24^{\mathrm{f}}$ \\
ABA MO & $9.02 \pm 0.25^{\mathrm{b}}$ & $132.75 \pm 1.62^{\mathrm{e}}$ & $253.27 \pm 1.57^{\mathrm{d}}$ & $145.27 \pm 0.95^{\mathrm{e}}$ & $20.05 \pm 0.35^{\mathrm{b}}$ \\
IND+MO & $9.04 \pm 0.16^{\mathrm{b}}$ & $135.45 \pm 1.31^{\mathrm{e}}$ & $253.65 \pm 1.72^{\mathrm{d}}$ & $157.37 \pm 1.19^{\mathrm{d}}$ & $19.41 \pm 0.34^{\mathrm{b}}$ \\
ABA+IND+MO & $7.72 \pm 0.18^{\mathrm{c}}$ & $144.57 \pm 1.29^{\mathrm{d}}$ & $259.49 \pm 2.40^{\mathrm{c}}$ & $170.98 \pm 1.31^{\mathrm{b}}$ & $17.52 \pm 0.29^{\mathrm{c}}$ \\
\hline
\end{tabular}

Each value is a mean of 6 rats \pm S.E.M; Means having the same letters are not singificanly differ from each other, $p<0.05$.
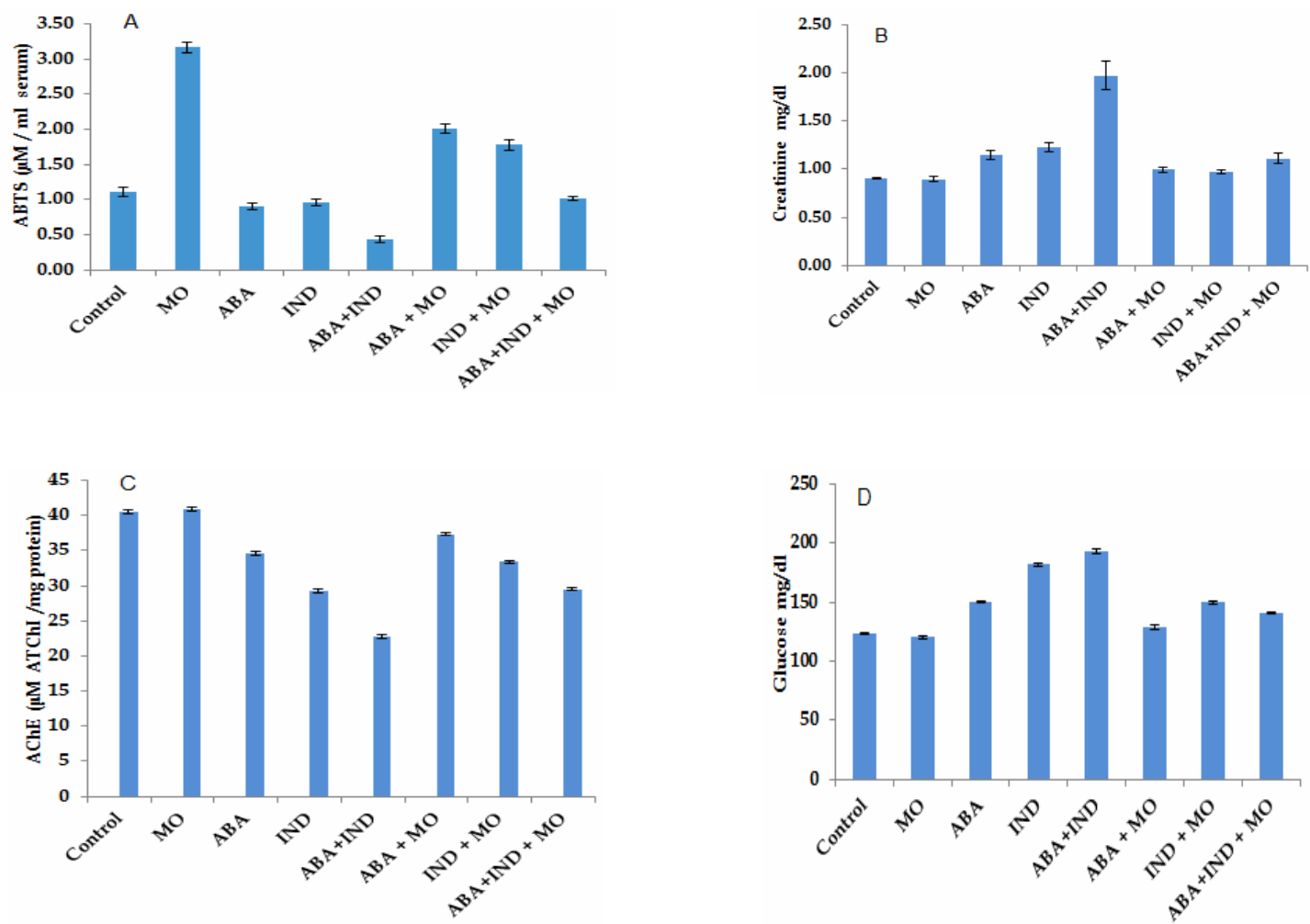

Figure1. Effect of the exposure to abamectin (ABA) and indoxacarb (IND) treatments on total antioxidant scavenging activity (A), serum creatinine $(\mathrm{B})$, acetylcholine esterase $(\mathrm{AChE})(\mathrm{C})$ and glucose $(\mathrm{D})$ of rat in the absence and presence of moringa extract $(\mathrm{MO})$. Data are expressed as mean \pm S.E. of 6 rats

Moderate focal hepatic necrosis, fibroplasia in the portal triad, and focal hemorrhage were found in G5, G4, and G3, respectively. Mild focal hepatic necrosis, portal infiltration with inflammatory cells, and hyperplasia in the portal triad were associated with the insecticide treatments (Figures $2 \mathrm{C}, \mathrm{D}$, and E).

Kidney sections from rats in the control, G2, G6, and G8 groups showed normal cell histological structure of renal parenchyma (Figure 3 A). However, severe congestion of the renal blood vessels and vacuolation of the tubular epithelium cells were noticed in tissues of G4 and G3, respectively. Mild abnormalities in kidney were noticed as congestion of the renal blood vessels, vacuolation of renal tubular epithelium, focal tubular necrosis, and interstitial nephritis after the treatment with ABA, IND, and their combinations (Figure $3 \mathrm{~B}, \mathrm{C}$, and D). Other mild hypertrophy, congestion of glomerular tuft with thickening of the parietal layer of Bowman's capsule, congestion of renal blood vesseland 

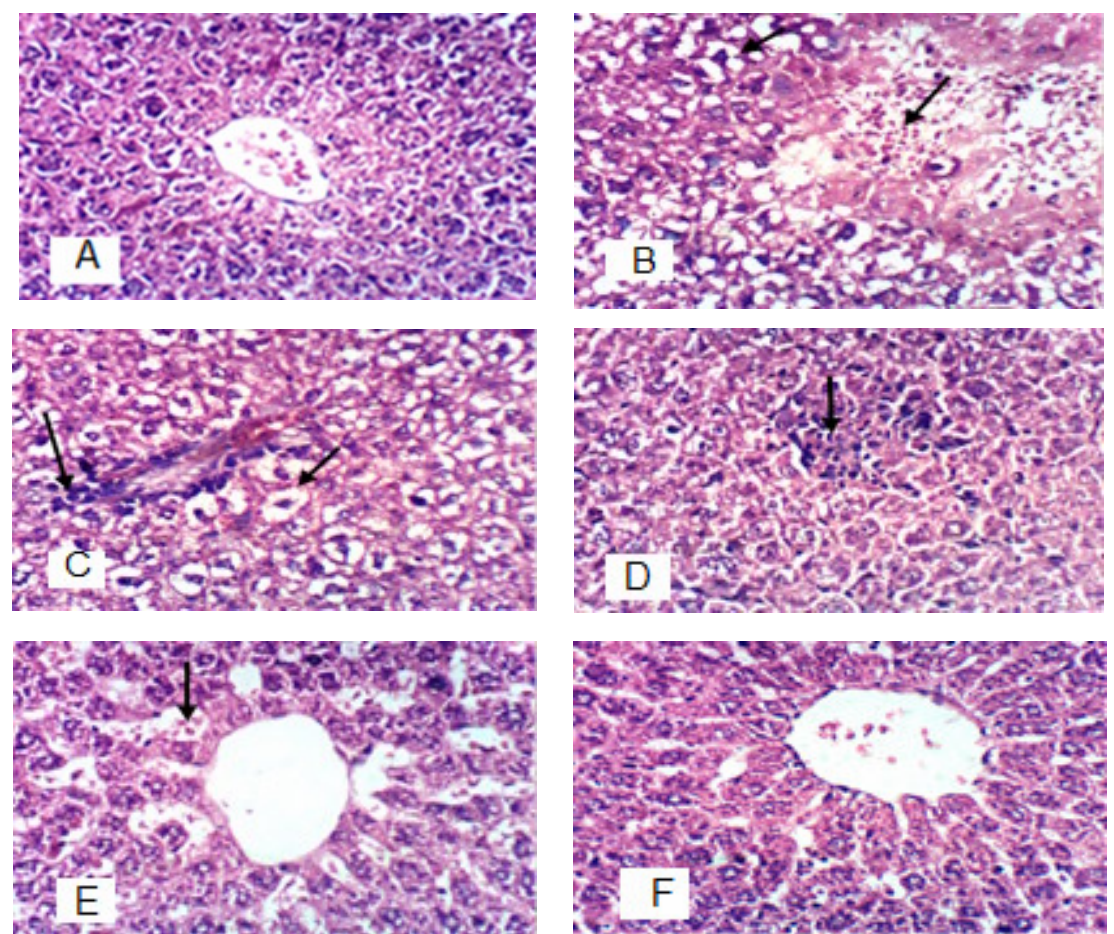

Figure 2. Histopathological examination of liver cells of rats (A) showed apparent normal hepatocytes in control and moringa extract (MO), (B) abamectin (ABA)-treated rats showed cytoplasmic vacuolation of hepatocytes and focal hepatic hemorrhage, (C) indoxacarb (IND)-treated rats showed cytoplasmic vacuolation of hepatocytes and portal infiltration with inflammatory cells, (D) ABA and INDtreated liver cells revealed focal hepatic necrosis associated with inflammatory cells infiltration (E), ABA +MO-treated rats had slight dilatation of hepatic sinusoids, (F) IND+MO- and ABA+IND+MO-treated rats had no histopathological changes. Specimens stained with hematoxylin and eosin (H and E; X 400).
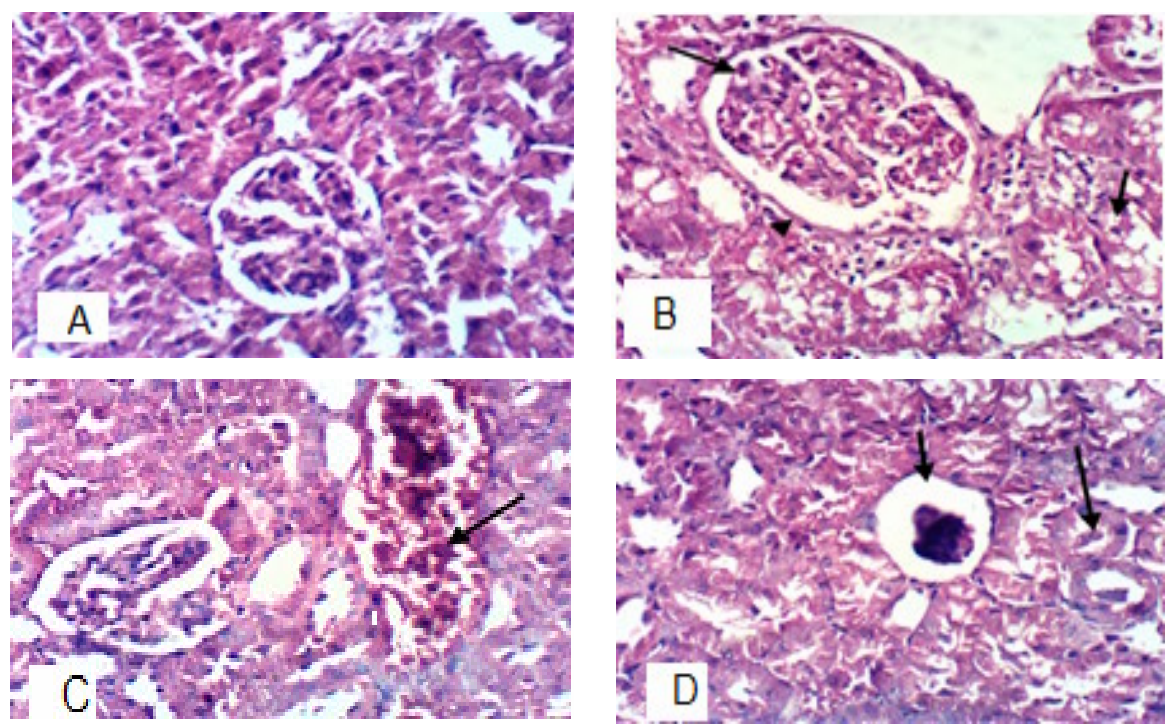

Figure 3. Histopathological profiles of kidney paraffin sections stained with hematoxylin and eosin (H\&E X 400) for (A) control group and Moringa showed normal histological structure of renal parenchyma, (B) ABA-treated rats had vacuolation of renal tubular epithelium, hypertrophy, and congestion of glomerular tuft with thickening of the parietal layer of Bowman's capsule, (C) IND-treated rats showed congestion of renal blood vessel, and (D) ABA+ IND -treated rats showed atrophy of glomerular tuft and presence of protein cast in the lumen of renal tubules, while MO plus to (B,C,D) showing no histopathological changes. 

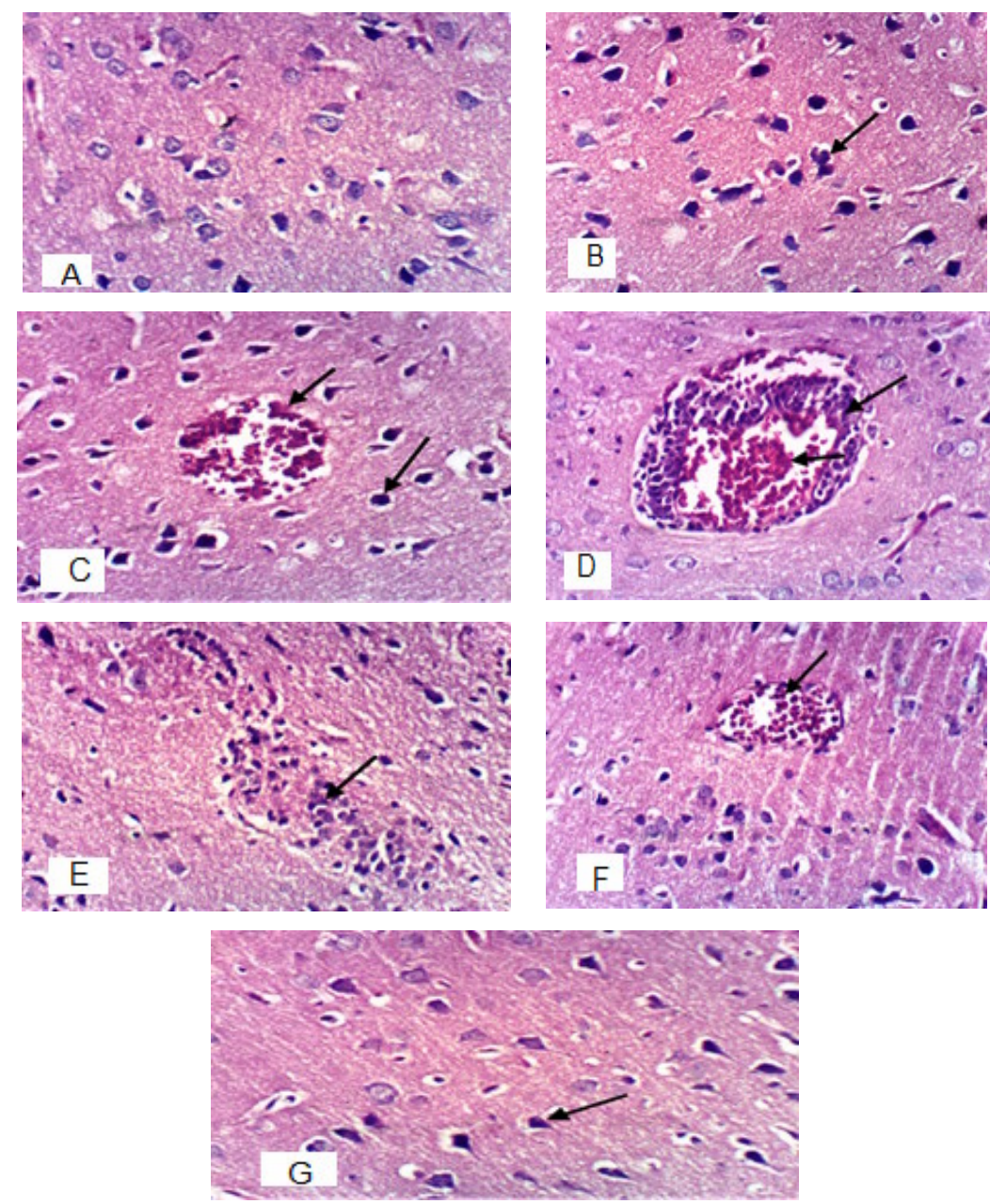

Figure 4. Histopathological examination of cells of brain tissue of (A) control and MO-treated rats showed no changes, (B) ABA-treated rats showed necrosis and pyknosis of neurons, (C) IND-treated rats showed congestion of cerebral blood vessel and necrosis of neurons, (D) ABA+IND-treated rats showed congestion of cerebral blood vessel and perivascular cuffing with mononuclear cells, (E) ABA+MOtreated rats showed focal gliosis, (F) IND+MO-treated rats showed congestion of cerebral blood vessel, and (G) ABA+IND+MO-treated rats showed necrosis of some neurons. Specimens stained with hematoxylin and eosin (H \& E X 400).

presence of protein cast in the lumen of renal tubules were observed (Figures $3 \mathrm{~B}, \mathrm{C}$, and D). On the other side, application of the MO extract with the tested insecticides showed different degrees of improve-ment in liver and kidney as compared to the treated groups alone.

Histopathological examination of brain tissues (Figure $4 \mathrm{~A}$ ) showed no changes in control and MOtreated rats. However, severe abnormalities resulted from the indoxacarb and ABA-IND mixture were noticed, showing necrosis, pyknosis of neurons (irreversible condensation of chromatin in the nucleus), congestion of cerebral blood vessel, and perivascular cuffing with mononuclear cells (Figure 4 B, C, and D). MO-treated rats with abamectin, indoxacarb, or their combinations showed mild to moderate focal gliosis, congestion of cerebral blood vessel, and necrosis of some neurons (Figures 4-G).

\section{DISCUSSION}

Enhancement the spectrum of pest control could be achieved when pesticide mixtures are used in the field, particularly, when multiple pests are attacking together. The pesticides distinguished in this study belong to two different classes of insecticides; ABA and IND which are relatively new insecticides with different mode of action and are being used extensively to control many pests on different crops. This study aimed to clarify the sub-acute exposure of the ABA and IND on histopathological, hematological and biochemical examination of the liver, kidney and brain of albino rats. Additionally, the prophylactic effect of aqueous leaves extract of MO against ABA and IND toxicity was also, considered. The results showed that the continuous exposure to ABA, IND and their mixture for 30 consecutive days had a significant decrease in body and kidney weight than untreated-control.Moreove, the 
absolute and relative weights of the liver and brain showed a significant $(\mathrm{p}<0.05)$ increase compared to the control. These results agreed with the findings reported by Eissa and Zidan (2010), who confirmed the ameliorative effect of MO extract treatments.

Liver plays a key role in the detoxification process for xenobiotics. Consequently, any injury or disturbance of its function results in hepatotoxicity and leading to health complications. Liver biomarker enzymes are commonly used for liver injury. In the present work, AST, ALT and ALP enzymes activities exhibited a significant increment, while $\gamma$-GT enzyme activity was decreased. It is well known that increased or decreased serum levels of biomarker enzymes in this study confirm the destruction of the hepatocytes by allowing these enzymes to leak into the circulation. Cellular leakage and loss of hepatocyte membrane integrity were indicated by Hsu et al. 2001; Sakr, 2007; KhaldounOularbi et al., (2013). This alteration is likely to affect the membrane permea-bility and provokes derangement in metabolites transport. Elevated liver enzymes are the cause of the muscle damage, hepatic injury and toxic hepatitis (Farkaset et al., 2004). The high activities of these enzymes could be referred to destruction of cells and the occurrence of damage to tissues and the accumulation of triglycerides and release enzymes into the blood stream, which have a clear indication of the emergence of necrosis cell of liver tissue (Alhazza, 2007). The decreased serum level of total proteins due to ABA, IND and their mixtures -treated rats reflects the liver toxicity as reported by Mudaraddi et al.,(2012). Liver is a major organ of protein synthesis and any disease in the liver can cause damage of hepatocytes with changes in protein and free amino acid metabolism leading to decreases synthesis and increase wasting via catabolism (Yousefet al., 2006; Wallace, 2007;ElShafey et al., 2011). Moreover, the increment in serum glucose level in insecticides-treated rats was associated with a significant increase in their daily water intake in order to counteract probably the increase of osmotic pressure and to establish homeostasis of the extracellular compartment as reported by Abdollahi et al (2004). Acetylcholinesterase (AChE) enzyme activity exhibited a significant decrease with the ABA, IND and their mixture administration compared to the control. $\mathrm{AChE}$ is centered at the cholinergic synapses and neuromuscular junctions in the CNS. The decrease of AChE due to the association with pesticide, which leads to complete inactivation of the enzyme. Then, the function of nervous system is distorted and results in the death of pests and mammals (Fournier and Mutero, 1994; Pohanka, 2014). Abamectin is harm to the environment and humans and had a great toxic effect on the growth and nervous systems (Kose et al., 2016).
Nassar, (2015) explained that, chemical structure of indoxacarb is different that on organophosphorus pesticides but the existence of the oxadiazin group might have some advantages.

Results, also, reflected the obvious significant increase in serum creatinine concentrations with the ABA, IND and their mixture administration compared to the control. The treated animals' elevation of creatinine concentrations may be attributed to the reduction in glomerular filtration in the kidney. Elevation of creatinine concentration is related to an elevated protein catabolism, where; the creatinine is the end product of protein catabolism and histopathological changes in the kidney. Such an elevation reflects the dysfunction of the kidney tubules (Walmsley and White, 1994). Significant adverse effects on the hematological parameters were reported after administering rats with ABA, IND and their mixtures. A significant decrease was noticed in the RBC, $\mathrm{Hg}$ and HCT, on the contrary WBC was significantly increased (Sandeep et al., 2016). Similarly, Lee et al., (2015) reported a methemoglobinemia after indoxacarb ingestion because of the aromatic metabolites that were biotransformed in to the active intermediates. The lower values in erythrocyte counts and haemoglobin concentration might be referred to the failure to supply the blood circulation with cells from haemohepatic tissues, since the liver has an important role in the regeneration of erythrocyte and the possible destructive effect on erythrocyte by the toxicants. The obtained results are in agreement with those found by Anubama et al., (2001)

Moringa-treated groups (MO, MO+ABA, MO+IND, or $\mathrm{MO}+\mathrm{ABA}+\mathrm{IND})$ of rats showed normal weight along with reduced the side effects of these insecticides. Some previous reports pointed out to an increase in the body weight of rats after eating MO leaves. This effect could be related to its rich content in amino acids, vitamins, and minerals particularly iron (Subadra et al., 1997; Faye, 2011). The MO has an impressive range of medicinal uses with high nutritional value. It is an important source of minerals, protein, vitamins, $\beta$ carotene, and amino acids which were confirmed in our study through the GC-MS analysis of the water extrac. Various parts of this plant such as the leaves, roots, seed, fruit and flowers act as cardiac and circulatory stimulants, anti-inflammatory, diuretic, antihypertensive,cholesterol lowering, antioxidant, antidiabetic, hepatoprotective, antifungal and antibacterial activities, and are being employed for the treatment of different ailments in the indigenous system of medicine (Anwar et al. 2007; Ola-Davies et al. 2014; Osman et al., 2015). M. oleifera leaf extracts contain poly-phenols; therefore the antioxidant effects of the leaf extract may depend on its phenolic components (Verma et al., 2009; Singh et 
al., 2014). It play important pharmacological properties, such as, antioxidant, anti-inflammatory, and antimutagenic properietes (Rasika et al., 2011). These antioxidant bioactive compounds effectively protect liver from hepatotoxic-induced toxicity. The leave extracts of $M$. oleifera, significantly, reduced chlorpyrifos-induced oxidative stress in rat brain, restored the brain enzymes, protein, the antioxidant capacity, and brain architecture (Oyewole and Olabiyi, 2014).

\section{CONCLUSIONS}

The present investigation indicated that $M$. oleifera has a potential role in therapeutic action via the presence of phenolic compounds and its antioxidant nature. However, further investigations are essential to explicate the accurate molecular mechanism of specific bio-active agents from moringa leaves for protection against abamectin and indoxacarb induced toxicity and it should be tested against various biologically important markers. Overall, it can be concluded that MO leaves bear a potent antioxidant activity. Finally, the obtained results confirmed the potential ameliorative effects of $\mathrm{MO}$ on $\mathrm{ABA}$ and IND-induced toxicity on albino rats.

\section{ACKNOWLEDGMENTS}

I'm grateful to Prof. Dr. Kawkab Abdel-Aziz Ahmed, Professor of Pathology, Faculty of Veterinary Medicine Cairo University for interpreting the histopathological sections.

\section{REFERENCES}

Abdel Rasoul, M.A., and G.Kh. Marei. 2016. Potential therapeutic effect of turmeric (Curcuma longa) against adverse effects of penconazole fungicide to white rats. International Journal of Pharmacology and Toxicology. 4 (2) : 178-186.

Abd-Elhady, H.K., G.E. and Abou-Elghar. 2013. Abamectin induced biochemical and histopathological changes in the albino rat, Rattus norvegicus. Journal of Plant Protection Research. 53: 263- 270.

Abdollahi, M., A. Ranjbar., S. Shadnia., S. Nikfar., and A. Rezaie. 2004. Pesticides and oxidative stress: a review Med. Sci. Monitor. 10: 141- 147.

Alhazza, I.M. 2007. Antioxidant and hypo-lipidemic effects of olive oil in normal and diabetic male rats. Saudi Journal of Biological Sciences. 14: 69-74.

Anubama, V.P., H. Honnegowda., K. Jayakumar., G. Krishnappa., K. Narayana., and Y.B. Rajeshwari. 2001. Effect of doramectin on immune response of rats to SRBC antigen. Indian Vet J. 78: 779-782.

Anwar, F., S. Latif., M. Ashraf., and A.H. Gilani. 2007. "Moringa oleifera: a food plant with multiple medicinal uses," Phytotherapy Research. 21( 1): 17-25.

Asiedu-Gyekye, I.J., S. Frimpong-Manso., C. Awortwe., D. A. Antwi., and A. K. Nyarko. 2014. Micro- and
Macroelemental Composition and Safety Evaluation of the Nutraceutical Moringa oleifera Leaves. Hindawi Publishing Corporation Journal of Toxicology.Article. ID 786979, $13 \mathrm{p}$.

Barham, D., and P. Trinder. 1972. An improved colour reagent for the determination of blood glucose by the oxidase system.Analyst. 97(151): 142-145.

Chapman, D., R. Castiilla., and J.Campbell. 1959. Evaluation of protein in food determination of protein and food efficiency ratio.Can. J. Biochem. Physil. 37 :676-86.

Eissa, F., and N. Zidan. 2010. Haematological, biochemical and histopathological alterations induced by abamectin and Bacillus thuringiensis in male albino rats. Acta Biol Hung. 61:33-44.

Ellman, G.L., K.D. Courtney., $\quad$ V. Andres., and R.M. Featherstone. 1961. A new and rapid colorimetric determination of acetylcholinesterase activity. Biochem Pharmacol. $7: 88-95$.

El-Shafey, A.M., M.E. Seliem., F. El-Mahrouky., W.M. Gabr., and R.A. Kandil. 2011. Some physiological and biochemical effects of Oshar extract and abamectin biocide on male albino rats. J. Am. Sci. 7 (12): 254-261.

Fakurazi, S., I. Hairuszah., and U. Nanthini. 2008. Moringa oleifera Lam prevents acetamino-phen induced liver injury through restor-ation of glutathione level. Food Chem. Toxicol. 46(8):2611-2615.

Farkaset, J., P. Farkas., and D. Hyde. 2004. Liver and gastroenterology tests, ini basic skills in interpreting laboratory data.Mary Lee 3rd Edition. American Society of Health System Pharmacists, Bethesda, Maryland. USA 330-336.

Faye, B., B. Bucheton., and A.L. Banuls. 2011. Prevalence of Leishmaniainfantum in a rural area of Senegal: analysis of risk factors involved in transmission to humans. J Trans R. Sco Trop Med Hyg. 105: 333 - 340.

Fournier, D., and A. Mutero. 1994. Modification of acetylcholinesterase as a mechanism of resistance to insecticides, Comp Biochem Physiol. 108C: 19-31.

Gonzalez, A., A. Sahagun., M.J. Diez., N. Fernandez., M. Sierra., and J.J. Garcia. 2009. The pharmacokinetics and metabolism of ivermectin in domestic animal species. The Veterinary Journal. 179:25-37.

Gornall, A.C., C.J. Bardawill., M.M. David., 1949. Determination of serum protein by means of biuret reaction. J. Biol. Chem. 177: 751-756.

Hsu, D.Z., C.H. Hsu., B.M. Huang., and M.Y. Liu. 2001. Abamectin effects on aspartate aminotransferase and nitric oxide in rats. Toxicology. 165:189-193

Huang, G.J., J.S. Deng., and S.S. Huang. 2012. Protective effect of androstenol from Antrodiacamphorata submerged whole broth against carbon tetrachloride-induced acute liver injury in mice. Food Chem. 132:709-16.

Khalafalla, M.M., E. Abdellatef., H.M. Dafalla., A.A. Nassrallah., K.M. Aboul-Enein., D.A. Lightfoot., F.E. ElDeeb., and H.A. El-Shemy. 2010. Active principle from Moringa oleifera Lam leaves effective against two 
leukemias and a hepatocarcinoma. Afr. J. Biotechnol. 9:8467-8471.

Khaldoun-Oularbi, H., C. Richeval., N. Djenas., M. Lhermitte., L. Humbert., and A. Baz. 2013. Effect of subacute exposure to, abamectin (insecticide) on liver rats (Rattus norvegicus). Ann Toxicol Anal. 25:63-70

Kolar, L., N.K. Erzen., L. Hogerwerf., and C.A. Van Gestel. 2008. Toxicity of abamectin and doramectin to soil invertebrates. Environ Pollut. 151:182-189

Kose, L.P., I. Gülçin., H. ? zdemir., A. Atasever., S.H. Alwasel., and C.T. Supuran. 2016. The effects of some avermectins on bovine carbonic anhydrase enzyme.Journal of enzyme inhibition and medicinal chemistry. 31(5):773-778.

Lee, D.K., H. Kim., and Y.S. Cha. 2015. Methaemoglobinaemia in acute indoxacarb poisoning. Emerg Med Australas. 27:376-377.

Mudaraddi, T.Y., R.R. Potadar., and B.B. Kaliwal. 2012. Indoxacarb induces liver oxidative stress in Swiss Albino Mice. European Journal of Experimental Biology. 2:180186

Nassar, AM. 2015. Acetylcholine esterase: A Universal toxicity biomarker. J.Agric.\&-Env.Sci.Dam.Univ.,Egypt. Vol.14 (1): 1-14.

National Research Council, 2011. Guide for the Care and Use of Laboratory Animals, 8th ed.; the National Academies Press: Washington, DC, USA.

Ndong, M., M.S. Uehara., I. Katsumata., and K. Suzuki. 2007. "Effects of oral administration of Moringa oleifera Lam on glucose tolerance in Goto-Kakizaki and wistar rats," Journal of Clinical Biochemistry and Nutrition. 40(3):229233.

Ola-Davies, O.E., S.G. Olukole., and O.A. Amoo. 2014. Haematological and serum biochemical variables in rats treated with ethanol extract of the root of Moringa oleifera. African J Biomed Res. 17:31-35

Osman, H.H., M.M. Ahmed., B. Osman., and A.M. Elhassan. 2015. Assessment of acute toxicity and LD 50 of Moringa oleifera ethanolic leave extract in albino rats and rabbits. J Med BiolSci Res. 1:38-43

Oyewole, O.I., and B.F. Olabiyi. 2014. Ameliorating Effect of Moringa oleifera Leaf Extract on Chlorpyrifos-Induced Toxicity in the Brain of Wistar Rats. Am J Biochem. 4:9397.

Park, J. S., H. Kim., S.W. Lee., and J.H. Min. 2011. Clin.Toxicol, 49: 744-746

Pohanka, M. 2014. Inhibitors ofacetylcholin-esterase and butyrylcholin-esterase meet immunity. Int. J. Mol. Sci. 15: 9809-9825.

Rasika, C. T., M. L. Sangita., and B.J. Ravindra., 2011. Evaluation of phenol and flavonoid content from aerial parts of Tecomastans.International Journal of Pharmacy and Pharmaceutical Science. 3(4).

Re, R., N. Pellegrini., A. Proteggente., A. Pannala., M. Yang., and C. Rice-Evans. 1999. Antioxidant activity applying an improved ABTS radical cationdecolorization assay. Free RadicBiolMed. 26: 1231-1237.

Reitman, S., and S.A. Frankel. 1957. Colorimetric method for the deter-mination of serum glutamic oxalacetic and glutamic pyruvic trans-aminases. Am. J. Clin. Pathol. 28: 56-63.

Sakr, S.A. 2007. "Ameliorative Effect of Ginger (Zingiber officinale) on Mancozeb Fungicide Induced Liver Injury in Albino Rats." Australian Journal of Basic and Applied Sciences. 1: 650656.

Sandeep, K., C. S. Mukhopadhyay., J. S. Arora., and R.S. Sethi. 2016. Indoxacarb interaction alters immunotoxic and genotoxic potential of endotoxin. J. Pestic. Sci. 41(3):65-70.

Sharma, N., P.C. Gupta., and C.V. Rao. 2012. Nutrient content, mineral, content and antioxidant activity of Amaranthusviridis and Moringaoleifera leaves. Res. J. Med. Plant. 6(3):253-259.

Shit, S.P., R.S. Panghal., V. Kumar., and R.D. Rana. 2008. Acute toxicity and gross behavioural effects of indoxacarb in laboratory animals. Haryana Vet. 47: 49-51.

Singh, D., P.V. Arya., V.P. Aggarwal., and R..S. Gupta. 2014. Evaluation of Antioxidant and Hepatoprotective Activities of MoringaoleiferaLam. Leaves in Carbon TetrachlorideIntoxicated Rats. Antioxidants. 3: 569-591.

Subadra, S., J. Monica., and D. Dhabhai. 1997. Retention and storage stability of beta-carotene in dehydrated $\mathrm{M}$. oleifera. Inter J Food Science and Nutri, 48:373 - 379.

Tietz, N.W. 1995. Clinical Guide to laboratory Tests. 3rd ed. Phila-delphia: WB Saunders,pp: 268-273.

Tomlin, C.D.S. (Ed.) 2004. A world compendium.The ePesticide Manual. Thirteen's Edition. Version 3.0 200304. British Crop Protection Council (BCPC).

Tomlin, C.D.S. 2005. The e-pesticide manual: a world compendium, Thirteen's Edition. British Crop Production Council, London

Verma, A.R. M. Vijayakumar., C.S. Mathela., and C.V. Rao. 2009. In vitro and in vivo antioxidant properties of different fractions of Moringa oleifera leaves; Food and Chemical Toxicology. 47: 2196-2201.

Von Stein, R.T., K.S. Silver., and D.M. Soderlund. 2013. Indoxacarb, metaflumi-zone, and other sodium channel inhibitor insecticides: Mechanism and site of action on mammalian voltage-gated sodium channels. Pestic Biochem Physiol. 106:101-112.

Vongsak, B., P. Sithisarn., W. Gritsanapan., 2012. "HPLC quantitative analysis of three major antioxidative components of Moringa oleifera leaf extracts," Planta Medica. 78(11):1252.

Wallace, A.H. 2007. Principles and Methods of Toxicology. Healthcare USA, Inc., New York, 5th ed. 369-453.

Walmsley, R.N., and G.H. White. 1994. A Guide to Diagnostic Clinical Chemistry. 3rd ed., Blackwell Publication, London, UK. 543 pp.

Whitfield, J.B., D.W. Moss., G. Neale., M. Orme., and A. Breckenridge. 1973. Changes in plasma -glutamyltrans- 
peptidase activity associated with alterations in drug metabolism in man. Br Med J. 10;1(5849) :316-318.

Wing, K.D., M.E. Schnee., M. Sacher., and M. Connair. 1998. Anoveloxadiazine insecticide is bioactivated in lepidopteran larvae. Archive Insect Biochem.Physiol.37:91-103.

Yang, Y.S., T.H. Ahn., J.C. Lee., C.J. Moon., S.H. Kim., W. Jun., S.C. Park., H.C. Kim., and J.C. Kim. 2008. Protective effects of Pycnogenol on carbon tetrachlorideinduced hepatotoxicity in Sprague-Dawleyrats.Food Chem. Toxicol. 46:380-387.
Young, D.S., L.C. Pestaner., and V. Gibberman. 1975. Effect of drug on clinical laboratory tests. Clinl. Chem. 21: D431-2.

Yousef, M.I., T. AwadI., and E.H.Mohamed. 2006. Deltamethrin-induced oxidative damage and biochemical alterations in rat and its attenua-tion by Vitamin E. Toxicology. 227(3):240-247.

Zanoli, J., M. Maioli., H. Medeiros., and F. Mingatto. 2012. Abamectin affects the bioenergetics of liver mitochondria: A potential mechanism of hepatotoxicity. Toxicol Vitr. 26:51-56. 


\section{الملخص العربي}

\section{تحسين التاثير السام لمركبات الابامكتين والأدوكسيكارب على ذكور الفئران باستخدام مستخلص نبات المورينجا \\ منى عبد النبى عبد الرسول}

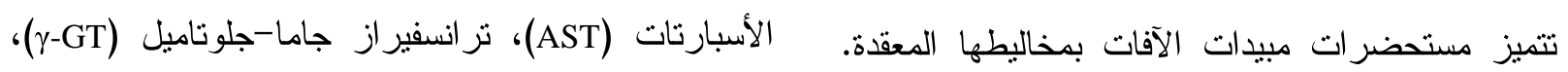

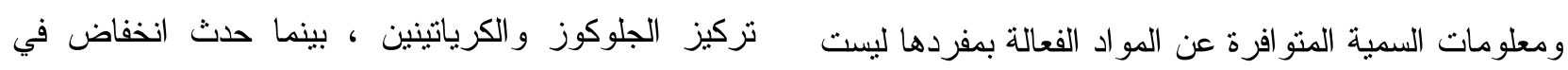
نشاط انزيم الاستيل كولين استريز (AChE) نتيجة المعاملة

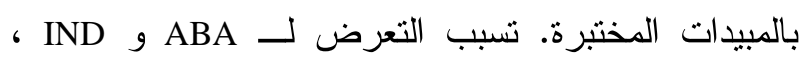
بشكل ملحوظ ، في انخفاض نشاط البروتين الكلي ومضاد

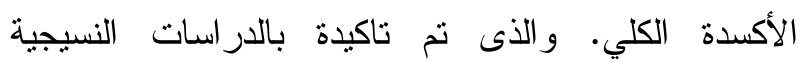

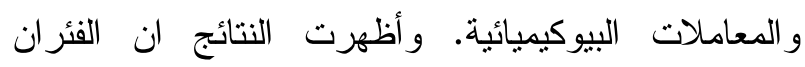
المعاملة بـالمستخلص المائى للمورينجا مع مبيدات ABA

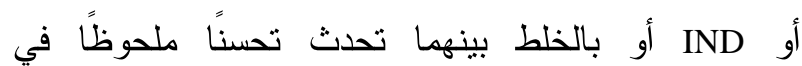

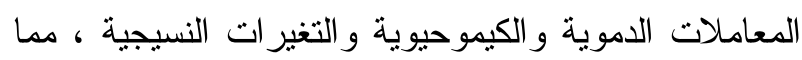
يشير إلى أن مستخلص المورينجا له نشاطاً قويًا كمضادًا للأكسدة ولذلك، يمكن استخدام المستخلص المائي لنبات المورينجا M. oleifera كثاي عشبي مفيدًا للمرضى الذين يعانون من أمر اض الكبد والكلى والمخ واستعادة الأضرار التي لحقت نتيجة التعرض للمبيدات. كلمات البحث: الفئران - الابامكتين - الاندوكسيكاربالدر اسات النشريحية- المورينجا. كافية لتقييم مخاطر الآثار الصحية غير المرغوبة لمبيدات الآفات الثائعة. لذلك ، تم اقتراح الدراسة الحالية لتوضيح

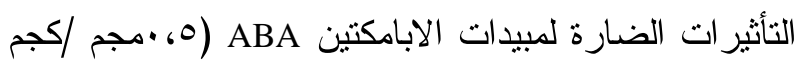
من وزن الجسم، / IND

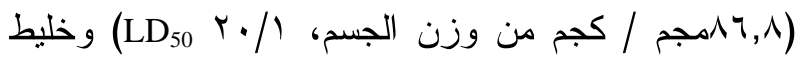
منهما على بعض المعايير الدموية والكيموحيوية والتغيرات النسيجية لذكور الفئران لجرعات فمية لمدة • ب يوم منتالية.

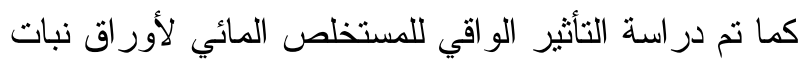
المورينجا (MO) ضد السمية التي تحدثها المبيدات الحشرية التى نم اختبارها. أشنارت النتائج إلى أن ABA و ومخاليطها، تسبب بشكل كبير في انخفاض تدريجي في

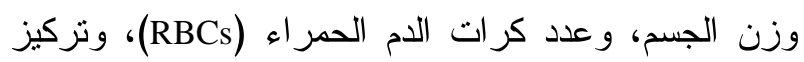

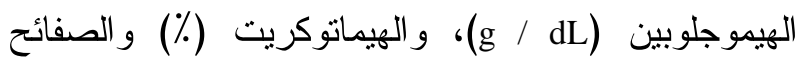
الدموية (PLT). مع حدوث ارتفاع كبير في الأوزان النسبية

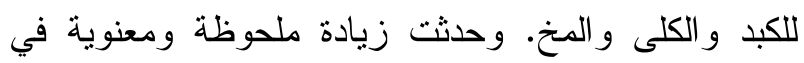

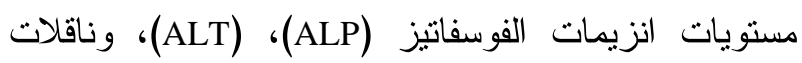

